\title{
TAX CODE OF UKRAINE: TERMINOLOGICAL PROBLEMS AND JUDICIAL PRACTICE
}

\begin{abstract}
The article presents Ukrainian solutions regarding the introduction of the Tax Code. The Tax Code of Ukraine is a progressive instrument of the national economic development that reflects measures for decreasing the tax burden on taxpayers (decreasing the profit tax rate), stimulating capital renewals (an introduction of the accelerated depreciation), and providing special investment incentives. This document stipulates the improved conditions for doing business: the reduction of the activities that require licenses, the decrease of licensing periods and tax benefits related to the reduction of rates. The purpose of the article is to presents terminological problems and judicial practice of the adoption of the Tax Code.
\end{abstract}

\section{Key words}

Tax code; judicial practice; terminological problems

\section{Introduction}

Adopted in 2010, the Tax Code of Ukraine (hereinafter - the TC of Ukraine) came into force in 2011. It regulates the relations arising from the collection of taxes and charges. In particular, it determines an exhaustive list of the taxes and charges levied in Ukraine and the procedure of their administration, as well as tax and levy payers, their rights and duties, competence of regulatory bodies, the powers and duties of their officials during tax control, and liability for the violation of the tax legislation. This Code defines functions and creates a legal framework of the regulatory bodies' activities.

\section{Main part}

The Tax Code of Ukraine is a progressive instrument of the national economic development that reflects measures for decreasing the tax burden on taxpayers (decreasing the profit tax rate), stimulating capital renewals (an introduction of the accelerated depreciation), and providing special investment incentives. This document stipulates the improved conditions for doing business: the reduction of the activities that require licenses, the decrease of licensing periods and the tax benefits related to the reduction of rates [Shevchenko 2014, p. 11].

The positive points of the adoption of the TC of Ukraine are as follows:

- the reduction of a number of tax laws (the laws handling matters of certain taxes have become ineffective);

- the reduction of the number of taxes and charges by abolishing those whose administration expenses have exceed their income (although, we disclose below the reverse side of such reduction and ineffectiveness);

- the unification of the terminology used for collection of all existing taxes (but this unification has gone beyond certain limits, we examine below the terminological problems of the TC of Ukraine);

- the attempt to unite the tax registration and accounting standards by terminology (but soon it has become clear that the TC of Ukraine is unable to cover the full accounting terminology and now Ukraine carries out further development and practical implementation of the International Financial Reporting Standards (IFRS) in parallel with the statutes of the tax law;

- the expansion of opportunities for tax reporting in electronic format. Today, the following national taxes (corporate income tax; individual income tax; VAT; excise tax; ecological tax; rent tax for the transportation of oil and petroleum products by petroleum pipelines and main product pipelines, and for the transit of natural gas and ammonia by pipelines across Ukraine; rent tax for oil, natural gas and gas 
condensate produced in Ukraine; extraction tax; land tax; flat agricultural tax), national charges (charge for the first registration of a vehicle; charge for the use of Ukrainian radio frequency resource; charge for the special use of water; charge for the special use of forest resources; charge for the development of wine, fruit and hop growing; additional levy to the current tariff rate for electricity and heat, except the electric power produced by special co-generation plants; additional levy to the current tariff rate for natural gas provided for consumers of all forms of ownership), local taxes (tax for immovable property, other than land plot; single tax; single tax for entrepreneurs-natural persons), and local charges (charge for parking space; tourist charge) can be reported in electronic format.

The statement is veracious asserting that 'despite the fact that the TC of Ukraine, with all its changes and improvements, affects positively the country development, its impact is not so great. The biggest problem here is not so much the Code as its sustainable violation and flouting in practice, disregard for strong rule of the law, and government corruption. Today this is a frequent occurrence when the tax authorities interpret the statutes of the law in different ways. In addition, the internal (informal) tax rules and interpretations are contrary not only to the Tax Code, but to each other as well' [Shevchenko 2014, p. 11].

The effective TC of Ukraine is highly controversial. Professor Kucheriavenko [2014, pp. 7-10] has generalized those contradictions. Based on his views and our own thoughts, we have indicated the following problems of the TC of Ukraine.

\section{Induced reduction of the number of the national taxes} and charges (from 30 to 19 , and later to 8). Before the TC of Ukraine was adopted, the Taxation System Act of Ukraine of 25.06.1991 was in force including 29 national taxes and charges (obligatory payments), and a single tax for small business was imposed by the Decree of the President of Ukraine "On simplified system of small business taxation, accounting and reporting" of 3.07.1998, No. $727 / 98$. Scientists rightly emphasize that the fact that the single tax for small business is not a part of taxes, charges, and obligatory payments listed in the Taxation System Act of Ukraine results from legislative negligence [Lysenkov 2010; Ped 2009, p. 416].

First, the TC of Ukraine included 18 national taxes and charges. In 2012 and 2014, the number of the national taxes and charges was amended to 7, and in December 2014, a military charge was imposed. So, in general,
8 national taxes and charges are levied today in Ukraine: corporate income tax; individual income tax; value added tax (hereinafter - VAT); excise tax; ecological tax; rent tax; custom duties; military charge.

Obviously, the adoption of the TC of Ukraine is aimed at eliminating either inefficient taxes and charges that do not provide a notable income (the fishery tax; the levy from dog-owners) or those ones which cannot be imposed throughout Ukraine (the resort levy; the joint fee levied at the checkpoint on the state border of Ukraine, etc.). At the same time, "in parallel with such a "cosmetic" reduction of tax payments, new taxes have been introduced (the tax for immovable property, other than land plot). Also, the tax base has been expanded on many taxes, and tax exemptions have been reduced [Kucheriavenko 2014, p. 8].

Problems of term definitions (Art. 14 of the TC of Ukraine). The article is one of the most important components of any regulatory legal act that defines its concept (glossary) and is one of the problems in the TC of Ukraine. In the amended TC of Ukraine as of April 2016, the Article 14 "Term definitions" contains the definitions of 280 terms and concepts that are thematically grouped to some extent, in other words, it has no general alphabetical order. In addition, the definitions are given throughout the Code, in other words, some definitions should be found by viewing individual articles.

Considering the glossary problems, Professor Kucheriavenko M.P. has grouped all the terms presented in Art. 14 of the TC of Ukraine as follows [Kucheriavenko 2014, pp. 8-9]:

a) terms borrowed from other legislation and reproduced without changes and any specificities for the tax and legal regulations (e.g. agricultural land (para. 14.1.76), railway land (para. $14.1 .78^{1}$ ), significant mineral resources (para. 14.1.79));

b) terms used exclusively in separate paragraphs of the TC of Ukraine (e.g. the term "time study" is defined in para. 14.1.264, and then mentioned only in Art. 80, para. 80.8 of the TC of Ukraine);

c) terms that are unlikely to be considered as fundamental legislative definitions that form the main approaches to the conceptual structure of the tax and legal regulations (composite motor fuel (para. 14.1.141), petrol (para. 14.1.141-1), beer (para. 14.1.144), recirculated gas (para. 14.1.216), time study (para. 14.1.264 etc.);

d) terms that cannot be used, in fact. The term "separate unit" is repeatedly mentioned in the TC of Ukraine (para. 14.1.222 of Art. 14, Art. 168, Art. 176). In 
addition, at the time when the TC of Ukraine was adopted, the Commercial Code of Ukraine was amended and the term was removed from its text, and the Civil Code of Ukraine uses terms "branch", "agency".

Some terms and categories are not mentioned in the TC of Ukraine, but they are used more in judicial decisions taken as the results of tax dispute resolutions. In particular, terms "good faith" and "bad faith" are often used concerning taxpayers in foreign tax practice. For example, the Decision of the Supreme Administrative Court of Ukraine of 30.10.2013 No. 804/366/13-a "On invalidation and revocation of tax assessment notices" [www.reyestr.court. gov.ua/Review/34532380 (accessed 20.09.2016)] indicates that the tax authority has reduced business expenses for the tax credit considering the absence of a counterparty by its location, and its subsequent bankruptcy.

According to the tax authority, these facts indicate the nullity of the agreement concluded because it is not aimed at ensuing real legal consequences. Revoking the tax assessment notices, courts proceeded from the fact that the term "prompt payer" used in tax legal matters does not require a payer's additional obligation to control its suppliers' compliance with the taxation rules, and the payer itself is not empowered to keep the tax control in order to perform the functions assigned to the tax authorities, and therefore, they cannot have the information concerning the performance of the tax obligations by counterparties... It is also noted that the judicial practice of tax dispute resolutions proceeds from the presumption of the good faith of payers and other participants of legal relations in the legal economy.

Therefore, it is presumed that the payer's actions that result in obtaining a tax benefit (in particular, in the form of a reduction of a tax base, profits tax, and value added tax to the amount of the expenses incurred due to the payment of a delivered product) are economically justified, and the information contained in the tax return and tax reporting is exact, unless the contrary is proved by the tax authority. In addition, the conclusion on the payer's unjustified tax benefit should be based on objective information that indubitably confirms the lack of a reasonable business purpose in the payer's actions and their focus solely on creating favourable tax consequences.

In the information letter of the Supreme Administrative Court of Ukraine of 20.07.2010 No. 1112/11/13-10 "Worries on application of legislation in matters involving the state tax authorities", the attention is drawn to the fact that 'there are common cases in practice when bad-faith members try to artificially create a negative difference between tax obligations and tax credit in the tax registration of value added tax, in order to unreasonably obtain funds from the state budget'. On the other hand, there are many cases of late VAT refunds to prompt taxpayers, particularly, to exporters. The above situation causes origins of numerous legal disputes between payers of value added tax and the tax authorities.

In case No. K/9991/81512/12, the Supreme Administrative Court of Ukraine stressed that the term "prompt payer" does not require a taxpayer's obligation to control its counterparties' compliance with the tax legislation, and a failure to such control cannot create negative consequences for this taxpayer (except when such actions are coordinated between a payer and its counterparty, or when a payer acts without proper diligence and caution). The Supreme Administrative Court of Ukraine made similar conclusions in case No. K/800/27906/14, noting that the presence or absence of certain documents, as well as errors in their execution shall not be cause for the conclusions on the lack of business operation, if other data indicates the actual assets flow or changes in owner's equity or liabilities of a taxpayer [www.kpmg.com/UA/en/IssuesAndInsights/ArticlesPublications/Tax-Dispute-Resolution-Update/Documents/Tax_Litigation_News_December_2014_uk.pdf (accessed 15.09.2016)].

By its decision of 31 October 2012 on the case No. K/9991/ 74364/11, the Supreme Administrative Court of Ukraine again applied the principle of the personalization of responsibility. According to the court decision, a prompt taxpayer shall not be liable for its counterparty's violations of the tax legislation. The Court explained that the Company cannot be responsible for the failure to pay taxes by its counterparty, if the case has no evidence confirming the agreement between the Company and its counterparty of the actions aimed at obtaining unjustified tax benefits. Being a prompt taxpayer, the Company is not obliged and authorized to control timely payments of tax by its counterparty.

Also, by its other decisions (in cases No. K/9991/71302/12 and No. K/ 800/15312/13), the Supreme Administrative Court of Ukraine has established a number of important criteria for defining a business purpose of business operation. In particular, if a tax purpose dominates a commercial one, a taxpayer's business purpose will be unfair. Therefore, the Court drew attention of judges to the following factors needed for establishing a taxpayer's goodfaith business purpose: a taxpayer's operations are aimed at receiving profit; a payer shall achieve a business purpose of the operation, and in case of failure to achieve, they provide the factors that prevented this; a payer shall have 
good economic reasons that are not related to obtaining tax benefits for such operations; a payer shall determine the market risks related to the operations performed; a payer shall allocate money for performance of such operations; the proportionality of the money allocated by a payer and resources for performance of the operations, and the received income, with regard to economic rationality and compliance of a payer's actions with rules of the commerce stream (Decision of 21.01.2015 in the case No. K/9991/71302/12; Decision of 20.01.2015 in the case No. K/800/15312/13) [www.kpmg.com/UA/en/IssuesAndInsights/ArticlesPublications/Documents/Tax_Litigation_News_March_2015_uk.pdf (accessed 10.10.2016)].

In the event of default by a bank on a payer's money transfer to a budget, the payer's tax obligation is considered to be settled upon the submission of necessary bank payment orders. It was decided by the Supreme Administrative Court of Ukraine in the case No. 815/5192/14 of 18.06.2015. In particular, the payer stated that he submitted the necessary payment orders to the bank, but the bank was in default on the payer's money transfer to the budget. The Supreme Administrative Court of Ukraine has determined that the payer's constitutional obligation to pay taxes shall be considered to be performed upon the submission of the payment order to the servicing bank on the transfer of funds from the payer's account to the budget system of Ukraine, on the account of the State Treasury, if the payer has enough money balance on the date of the payment. In addition, the payer is not liable for the actions of banks and credit institutions participating in the multistage process of payment and transfer of taxes to the budget. That is, if the payer has evidence that confirms the fulfilment of all the statutory conditions to recognise it as a prompt payer, the obligation of paying the appropriate amount of tax liability shall be considered to be performed, regardless of the actual payment transfer to the budget system of Ukraine.

Despite the obvious practical significance and necessity of using the term "good faith", the domestic judicial practice has not, unfortunately, prompted the Verkhovna Rada of Ukraine to amend the TC of Ukraine and fix the term "good faith", as well as good faith criteria in it. This is the case when lawmakers "do not hear" the results of judicial practice.

The problem of sanctions. In Art. 14, para. 14.1.265, the Tax Code provides the definition of the term "forfeit penalty (financial penalty, fine)". This is a payment in the form of a fixed amount and/or interest levied from a taxpayer due to the their breach of the requirements of tax and other legislations, the compliance of which is controlled by the regulatory authorities, as well as penalties for violations in foreign economic activities. Hence, 'at least two questions arise: what is the difference between fines and penalties (if a fine means a penalty); and why is it said about a number of penalties, when just one penalty - a fine - is applied from the entire system of financial penalties?' [Kucheriavenko 2014, p. 9]. It is even more interesting further. In Art. 111 of the TC of Ukraine, it is noted that 'the financial responsibility for violation of laws on taxation and other laws is applied in the form of forfeit (financial) penalties (fines) and/or surcharges. However, it is not defined in the Code what a "forfeit penalty" or "financial penalty" is. In the subparagraph "e" of para. 176.1 of Art. 176, forfeit (financial) penalties are mentioned (why not penalties or fines? Obscurely...). Art. 113-116 of the TC of Ukraine considers actually forfeit (financial) penalties (fines), and Art. $123^{1}$ considers penalties (and all this is presented within the same chapter "Responsibility").

Physical checks. Part 1 of Art. 75 of the TC of Ukraine stipulates that the regulatory authorities are entitled to conduct desk audits, office audits (routine or unscheduled, field or remote audits) and physical checks'. The latter - physical check - mostly raises questions, which is conducted at the location of carrying on the taxpayer's actual business, at the location of economic or other items of the taxpayer's property, without prior notice to them. According to Art. 80, para. 80.2 of the TC of Ukraine, a physical check can be conducted under the decision of the head of the regulatory authorities, which is issued under an order. Although, Art. 80 provides an exhaustive list of the circumstances in which such checks are possible to be conducted, but the regulatory authorities have quickly found the possibility of abusing their rights in order to conduct physical checks (with great desire and need you can always find a necessary ground).

In accordance with Art. 94, para. 94.2 of the TC of Ukraine, an administrative arrest of a taxpayer's property can be applied, if they reject the conduct of desk audit or physical check, given legal basis for its conduct, or admission of the officials of the regulatory authorities. It should be noted that in 2015 the Art. 94, para. 94.2 of the TC of Ukraine was amended, and before then, the paragraph had mentioned about the rejection of conducting a desk audit. Those changes were a positive reaction to the controversial judisial practice on this issue. For example, two officials of the State Fiscal Service of Ukraine came to the Limited Liability Company "A" in order to conduct a physical check. 
A chief accountant acquainted with the materials and rejected the conduct as well as the admission to the physical check, giving as a reason that the director was absent. Let us consider different judgments on this case.

In its decision of 3.04.2013 on the case No. 810/1552/13-a, Kyiv District Administrative Court notes that 'the application of Art. 94 of the TC of Ukraine is possible, if the taxpayer rejects the conduct of only a desk audit... The taxpayer's rejection of admission of the officials of the State Tax Service aiming to conduct a physical check cannot be a base for the application of the administrative arrest of the taxpayer's property, as the current legislation does not allow to use the administrative arrest of a property in the case of a taxpayer's rejection of conducting a physical check' (emphasis added. - O.M.-C.).

In its decision of 15.10 .2013 on the case No. 2a/2370/4023/12, Kyiv Appeal Administrative Court notes that based on the definitions of a desk audit and a physical check, it can be concluded that a physical check is a subtype of a desk audit, but it covers more or less narrow range of issues to be checked. Based on the above, the Court fulfilled the filing of the tax authorities on the validity of the arrest in virtue of the requirements of paragraphs 94.2.3, 94.2 of Art. 94 of the TC of Ukraine (emphasis added. - O.M.-C.). Namely, the Court applied a broad interpretation of the norm and the analogy of law that is not of its jurisdiction.

In the decision of the Supreme Administrative Court of Ukraine of 15.09.2014 No. K/800/55020/13 “On confirmation of validity of an administrative arrest of a taxpayer's property", the court concluded that 'the concept of rejection of auditing and the concept of rejection of the admission to audit have separate legal substances, and therefore, they shall be considered as non-identical concepts. Therefore, there are grounds to believe that the claims of Art. 94, para. 94.2, subparagraph 94.2.3 of the TC of Ukraine are applied to the cases of arresting a taxpayer's property in case of: either rejection of desk auditing, or non-admission to any kind of audit, if the admission is to be applied for such audit. So, the arrest of assets can be applied both by the rejection of the admission to a desk audit, and the rejection of the admission to other type of audit, including physical check' (emphasis added. - O.M.-C.). It is a positive thing that the judicial practice was finally taken into consideration by the Verkhovna Rada of Ukraine, and the TC of Ukraine was consequently amended.

\section{Conclusion}

We have considered only a few problem points of the TC of Ukraine. Of course, there are other issues as well that could be subjected to independent scientific research. In any case, the adoption of the codified act that comprehensively regulates tax relations in the country is an important step in the legislative process. Finally, we note that: tax law will never satisfy both taxpayers and regulatory bodies representing public financial interests, especially the interests of the country. For a taxpayer, as British Prime Minister Winston Churchill said, 'there are no good taxes', on the other hand, as French lawyer, writer and political thinker Charles Louis Montesquieu argued, 'a tax inspector is one who cares more for how you spend your money than how a government spends them'.

\section{Bibliography}

Bulletin of tax dispute resolutions [online], www.kpmg.com/ UA/en/IssuesAndInsights/ArticlesPublications/Tax-Dispute-Resolution-Update/Documents/Tax_Litigation_ News_December_2014_uk.pdf (accessed 15.09.2016).

Bulletin of tax dispute resolutions of 17 March 2015 [online], www.kpmg.com/UA/en/IssuesAndInsights/ArticlesPublications/Documents/Tax_Litigation_News_ March_2015_uk.pdf (accessed 10.10.2016).

Kucheriavenko M.P. (2014), Conflicts of the Tax Code of Ukraine, "Financial Law" No. 2.

Lysenkov Y.M. (2010), The main developments of the Tax Code of Ukraine concerning taxes, [in:] Y.M. Lysenkov, S.O. Bida, Electronic scientific specialized edition "Effective economics" No. 12 [online], www.economy.nayka. com.ua/?op=1\&z=417 (accessed 12.10.2016).

Ped' I.V. (2009), Tax competition: Monograph, K.: Expert Consulting.

Shevchenko N. (2014), The Tax Code of Ukraine: development, impact and applications, [in:] N. Shevchenko, T. Otten, Institute for Economic Research and Political Consultations, $\mathrm{K}$.

The decision of the Supreme Administrative Court of Ukraine of 30.10.2013 No. 804/366/13-a "On invalidation and revocation of tax assessment notices" [online], www.reyestr. court.gov.ua/Review/34532380 (accessed 20.09.2016).

\section{Author biography:}

Oksana Muzyka-Stefanchuk - Professor of the Department of Constitutional, Administrative and International Law of the Bohdan Khmelnitsky National Academy of State Border Service of Ukraine. 